\title{
Short communication: Effect of delaying the first colostrum feeding on small intestinal histomorphology and serum insulin-like growth factor-1 concentrations in neonatal male Holstein calves
}

\author{
A. J. Fischer-Tlustos, ${ }^{1}$ J. Pyo, ${ }^{2}$ Y. Song, ${ }^{3}$ D. L. Renaud, ${ }^{4}$ L. L. Guan, ${ }^{2}$ and M. A. Steele ${ }^{1,2 *}$ \\ ${ }^{1}$ Department of Animal Biosciences, Animal Science and Nutrition, University of Guelph, Guelph, ON, Canada N1G 1 Y2 \\ ${ }^{2}$ Department of Agricultural, Food and Nutritional Science, University of Alberta, Edmonton, AB, Canada T6G 2P5 \\ ${ }^{3}$ College of Animal Science and Technology, Inner Mongolia University for Nationalities, Tong Liao, Inner Mongolia, 028000, China \\ ${ }^{4}$ Department of Population Medicine, University of Guelph, Guelph, ON, Canada N1H 2W1
}

\section{ABSTRACT}

The primary objective of this study was to determine the effect of delaying the first colostrum feeding on small intestinal histomorphology and serum insulin-like growth factor-1 (IGF-1) concentrations, and the secondary objective was to characterize the ultrastructure of the small intestine of neonatal calves at $51 \mathrm{~h}$ of life. Twenty-seven male Holstein calves were fed pooled, pasteurized colostrum (7.5\% of birth body weight; $62 \mathrm{~g}$ of $\mathrm{IgG} / \mathrm{L})$ at $45 \mathrm{~min}(0 \mathrm{H}, \mathrm{n}=9), 6 \mathrm{~h}(6 \mathrm{H}, \mathrm{n}=9)$, or 12 $\mathrm{h}(12 \mathrm{H}, \mathrm{n}=9)$ after birth. At $12 \mathrm{~h}$ after their respective colostrum feeding, calves were fed milk replacer at $2.5 \%$ of birth body weight per meal and every $6 \mathrm{~h}$ thereafter. Blood samples were collected every $6 \mathrm{~h}$ using a jugular catheter and analyzed for serum IGF-1 concentrations using an automated solid-phase chemiluminescent immunoassay. At $51 \mathrm{~h}$ of life, calves were euthanized to facilitate collection of the duodenum, proximal and distal jejunum, and ileum. All segments of the small intestine were assessed for histomorphology, whereas scanning electron and transmission electron microscopy analyses were conducted only for the proximal jejunum and ileum. The results revealed that there was no overall effect of colostrum feeding time on serum IGF-1 concentrations; however, serum IGF-1 concentrations were influenced by time. Specifically, concentrations of serum IGF-1 at $48 \mathrm{~h}$ were $29 \%$ greater than concentrations at $0 \mathrm{~h}$ of life $(312.8 \pm 14.85$ vs. $241.9 \pm 14.06 \mathrm{ng} / \mathrm{mL})$. Although there was no overall effect of colostrum feeding time on all histomorphological measures assessed, treatment $\times$ segment interactions were observed. Villi height was 1.4 times greater in the distal jejunum of $0 \mathrm{H}$ calves than in $6 \mathrm{H}$ and $12 \mathrm{H}$ calves, and $0 \mathrm{H}$ calves tended to have 1.2 times greater ileal villus height than $12 \mathrm{H}$ calves. In

Received May 27, 2020.

Accepted July 29, 2020.

*Corresponding author: masteele@uoguelph.ca addition, $0 \mathrm{H}$ calves had 1.2 and 1.3 times greater ileal crypt depth than $6 \mathrm{H}$ and $12 \mathrm{H}$ calves, respectively, and 1.3 times greater surface area index than $12 \mathrm{H}$ calves in the distal jejunum. Qualitative ultrastructural evaluation of small intestinal enterocytes conducted irrespective of colostrum treatment revealed the presence of large vacuoles of electron-dense material, apical mitochondria, and apical canalicular systems in the jejunum and ileum. These results indicate that the calf intestine at $51 \mathrm{~h}$ of life contains unique enterocyte characteristics similar to fetal enterocytes and that delaying colostrum feeding may negatively influence intestinal growth and development.

Key words: newborn calf, colostrum, intestinal growth, insulin-like growth factor-1

\section{Short Communication}

The absorption of IgG from colostrum is fundamental in ensuring the health and survival of the neonatal calf (Weaver et al., 2000). The most important factors ensuring the successful passive transfer of IgG include feeding adequate volumes of high-quality colostrum in a timely manner after birth (Godden et al., 2019). Despite this knowledge, 41 and $23 \%$ of Canadian dairy producers reported only occasionally or never feeding colostrum overnight, respectively (Winder et al., 2018), which is when the majority of calvings occur (von Keyserlingk and Weary, 2007). This results in many calves being fed colostrum after $6 \mathrm{~h}$ postnatal (Vasseur et al., 2010), which can reduce serum IgG concentrations by $28 \%$ compared with calves fed at $1 \mathrm{~h}$ after birth (Fischer et al., 2018). Furthermore, delaying colostrum feeding up to $12 \mathrm{~h}$ of life tends to reduce the prevalence of beneficial epimural bacteria in the colon (Fischer et al., 2018) and is associated with an increased abundance of opportunistic pathogens in the ileum (Ma et al., 2019). These findings indicate that delaying the first colostrum meal can significantly influence not only 
passive transfer but also gastrointestinal (GI) development. However, there is currently a lack of research characterizing how colostrum feeding time may influence indicators of growth and GI development.

Research has demonstrated that depressed ADG during the preweaning period is associated with reduced future milk production (Soberon et al., 2012). Therefore, elucidating early-life feeding strategies that positively influence preweaning calf growth is important in ensuring future profitability and sustainability of dairy operations. The small intestine is the main site of absorption and digestion in young ruminants, and thus its development and function can largely influence calf growth. Colostrum contains an abundance of nutritional and bioactive factors that can promote intestinal development and growth (Blum and Hammon, 2000), including IGF-1 (Bühler et al., 1998; Jehle et al., 1999). Furthermore, colostral nutrients have been hypothesized to stimulate endogenous production of IGF-1 (Hadorn et al., 1997; Cordano et al., 1998). Previous work by Hammon et al. (2000) found that calves fed the first colostrum meal at $24 \mathrm{~h}$ postnatal had lower serum IGF-1 concentrations compared with calves fed within $2 \mathrm{~h}$ postnatal, demonstrating that the inability to provide colostrum in a timely manner affects IGF1 status in plasma. Considering the effect of delayed feeding of colostrum on circulating IGF-1 concentrations (Hadorn et al., 1997; Hammon et al., 2000), it is possible that the timing of colostrum feeding and subsequent delivery of macronutrients and colostral bioactive components may consequently affect the growth and development of the small intestine. Previous work has shown that feeding multiple meals of colostrum can have trophic effects on intestinal structure compared with feeding milk replacer or whole milk (Bühler et al., 1998; Blättler et al., 2001; Pyo et al., 2020), further demonstrating the importance of colostrum feeding in promoting GI development. Unfortunately, there is a lack of research characterizing how delaying the first colostrum meal may influence intestinal histomorphological parameters.

We hypothesized that, due to the early delivery of colostral nutrition and bioactive compounds, calves fed colostrum within the first hour of life would have increased small intestinal development and circulating IGF-1 concentrations compared with calves fed later in life. Therefore, the primary objective of the study was to determine the effect of delaying the first colostrum feeding on small intestinal histomorphological parameters and serum IGF-1 concentrations. In addition, there is a paucity of knowledge pertaining to the effects of feeding the current recommended volume and quality of colostrum (approximately $3-4 \mathrm{~L}$ and $>150 \mathrm{~g}$ of $\mathrm{IgG}$; Godden et al., 2019) on small intestinal morphology.
Thus, a secondary objective was to characterize the morphology and ultrastructure of the small intestine of neonatal calves at $51 \mathrm{~h}$ of life.

The experimental procedures reported were conducted under the approval of the University of Alberta Animal Care and Use Committee (AUP00001595) at the Dairy Research and Technology Centre of the University of Alberta (Canada), which was chosen for its resources (surgery suite, 24/7 calving surveillance, individual calf pens) and proximity to the University of Alberta. Detailed information regarding animal feeding, management, sample collection, euthanization, and dissection is provided in Fischer et al. (2018); however, the methods are described briefly herein. Using the RAND command in Microsoft Excel (Microsoft Corp., Redmond, WA), singlet male Holstein calves $(\mathrm{n}=27)$ were randomly allocated by the research team to 1 of 3 treatment groups: calves fed colostrum at $45 \mathrm{~min}$ after birth $(\mathbf{0 H}, \mathrm{n}=9)$, at $6 \mathrm{~h}$ after birth $(\mathbf{6 H}, \mathrm{n}=9)$, or at $12 \mathrm{~h}$ after birth $(\mathbf{1 2 H}, \mathrm{n}=9)$. The selected number of animals was determined from previously generated calf data pertaining to small intestinal histology measurements and IGF-1 concentrations during the first days of life (Pyo et al., 2020) to provide a power of 0.80 at a level of significance of 0.05 to detect a difference among treatments. Within each treatment group, 5 calves were born from multiparous cows (average parity $=3.5 \pm 0.3$ ) and 4 calves were born from heifers. Calves were removed from the dam immediately after birth, weighed, and transferred to individual pens bedded with shavings and fresh straw. Regardless of treatment group, all calves were fed from a single batch of pooled, pasteurized bovine colostrum containing $62 \mathrm{~g}$ of IgG/L provided by the Saskatoon Colostrum Co. Ltd. (Saskatoon, SK, Canada). All colostrum was stored at $-20^{\circ} \mathrm{C}$ and thawed in a water bath kept at a consistent temperature and heated to $39^{\circ} \mathrm{C}$ before feeding. Calves were fed colostrum at $7.5 \%$ of birth BW at their respective feeding time via an esophageal tube feeder. Beginning at $12 \mathrm{~h}$ after their respective colostrum feeding, calves were fed milk replacer (MR, $150 \mathrm{~g}$ of MR powder/L; Excel Pro-Gro Calf Milk Replacer, Grober Nutrition, Cambridge, ON, Canada; 26:18 CP:fat ratio) at $2.5 \%$ of BW per meal via nipple bottle every $6 \mathrm{~h}$ until $51 \mathrm{~h}$ of life.

Baseline serum samples were collected at approximately 20 min of life from the jugular vein using a Vacutainer (Becton, Dickinson, and Co., Franklin Lakes, NJ), after which a 2-inch, 16-gauge jugular catheter (Terumo Medical Corp., Somerset, NJ) was inserted at $2 \mathrm{~h}$ of life. Serum samples $(5 \mathrm{~mL})$ were collected every $6 \mathrm{~h}$ of life for determination of serum IGF-1 concentrations. After clotting at room temperature for $3 \mathrm{~h}$, samples were centrifuged at $3,000 \times g$ at $4^{\circ} \mathrm{C}$ for $20 \mathrm{~min}$ 
and supernatant was collected and frozen at $-20^{\circ} \mathrm{C}$. Approximately $1.5 \mathrm{~mL}$ of serum was shipped overnight on ice to the Western College of Veterinary Medicine (Saskatoon, SK, Canada), where IGF-1 analysis was performed using an automated solid-phase chemiluminescent immunoassay kit in conjunction with an Immulite/Immulite 1000 System (Siemens AG, Munich, Germany) calibrated according to the instructions provided by the manufacturer. The inter- and intra-assay coefficient of variation for IGF-1 analysis were 5.1 and $4.5 \%$, respectively. The area under the curve (AUC) was calculated for IGF-1 using an equation based on the trapezoidal rule. The total AUC was also calculated relative to the first $12 \mathrm{~h}\left(\mathrm{AUC}_{12}\right), 24 \mathrm{~h}\left(\mathrm{AUC}_{24}\right)$, and 36 $\mathrm{h}\left(\mathrm{AUC}_{36}\right)$ after colostrum feeding.

At $51 \mathrm{~h}$ of life ( $3 \mathrm{~h}$ after the final meal), calves were weighed and euthanized using a pentobarbital sodium injection (Euthanyl, Vetoquinol, Lavaltrie, QB, Canada) via the jugular catheter at $0.125 \mathrm{~mL} / \mathrm{kg}$ of $\mathrm{BW}$ as described by Fischer et al. (2018). Small intestinal samples $(10 \mathrm{~cm})$ were collected from the duodenum, proximal jejunum, distal jejunum, and ileum according to the predetermined regions described by Malmuthuge et al. (2015), and attached omentum and fat tissue was discarded. After sample collection, the weight (devoid of intestinal digesta) and length of the duodenum, jejunum, and ileum were recorded and divided by calf BW at time of killing to determine the length $(\mathrm{cm})$ and weight (g) per kilogram of BW. From each 10-cm intestinal sample, a cross-section was immersed in $15 \mathrm{~mL}$ of formaldehyde for brightfield microscopy. Within 48 $\mathrm{h}$ after collection, all samples were transferred to Histocore Facility (University of Alberta, Edmonton, AB, Canada) for further processing as described by Pyo et al. (2020). Villus height and crypt depth were measured as described by Pyo et al. (2020) using Image J software (ImageJ, National Institutes of Health, Bethesda, MD). For each calf, 2 measurements from 5 different images per slide were captured per small intestinal compartment under $100 \times$ magnification, yielding a total of 10 measurements per region. Villus:crypt ratios were calculated by dividing the villus height values by crypt depth values as an indicator of intestinal integrity and differentiation (Jeurissen et al., 2002). The mucosal surface area index was estimated using the mucosal: serosal amplification ratio (Kisielinski et al., 2002).

To qualitatively assess small intestinal morphology and ultrastructure, small pieces ( $\leq 2 \mathrm{~mm}$ in length) of the proximal jejunum and ileum were placed in $2 \mathrm{~mL}$ of fixative $(2.5 \%$ glutaraldehyde and $2 \%$ paraformaldehyde) for scanning electron microscopy (ScEM) and transmission electron microscopy (TEM) in 3 calves per treatment selected randomly using the RAND command in Microsoft Excel. All samples were processed according to Bozzola and Russell (1992). In brief, TEM samples were post-fixed with $1 \%$ osmium tetroxide in $0.1 M$ phosphate buffer. Both ScEM and TEM samples were dehydrated using a series of ethanol solutions. Dehydrated ScEM samples were placed on an adhering carbon tape and coated with nickel alloy particles using the Hummer 6.2 sputter coater (Anatech USA, Hayward, CA). Coated samples were viewed under a Philips-FEI (Hillsboro, OR) XL30 scanning electron microscope. Dehydrated TEM samples were immersed in Spurr's low-viscosity resin and sectioned using an Ultracut E Ultratome (Leica Microsystems, Concord, ON, Canada). Silver-gold sections (80-100 nm) were placed on 300-px copper grids (Electron Microscopy Sciences, Hatfield, PA) followed by uranyl acetate and lead citrate staining. The grids were viewed under a Morgagni 268 TEM (Phillips-FEI) to assess intestinal ultrastructure.

Statistical analysis was conducted using SAS (version 9.4; SAS Institute Inc., Cary, NC), and data sets were analyzed for descriptive statistics and normality using the UNIVARIATE procedure of SAS. Data were identified as homoscedastic by visual inspection of distribution plots. Serum IGF-1 concentrations were analyzed using the MIXED procedure of SAS, with treatment and time and their interaction as fixed effects and calf considered a random variable. Body weight, ADG, and AUC parameters calculated using serum IGF-1 concentrations were analyzed using the MIXED procedure, with the fixed effect of treatment and calf considered a random variable. For intestinal lengths, weights, and all histology parameters, data were analyzed using calf as a random variable and treatment and intestinal segment and their interaction as fixed effects. Significance was declared at $P<0.05$ and tendencies were discussed at $0.05<P<0.10$. All values reported are least squares means.

There were no differences in calf $\mathrm{BW}$ at birth or at the time of killing or in ADG between treatment groups $(P>0.80$; Table 1$)$. There was no effect of treatment on serum IGF-1 concentrations $(P=0.31)$, total area under the curve from 0 to $48 \mathrm{~h}$ of life, and $\mathrm{AUC}_{36}(P$ $>0.19)$; however, $6 \mathrm{H}$ calves had a higher $(P=0.04)$ $\mathrm{AUC}_{12}$ and tended to have a higher $(P=0.07) \mathrm{AUC}_{24}$ than $0 \mathrm{H}$ calves (Table 1$)$. A treatment $\times$ time interaction was observed for serum IGF-1 concentrations ( $P$ $<0.0001$ ), where $6 \mathrm{H}$ calves had higher serum IGF-1 concentrations at $6 \mathrm{~h}$ of life compared with $0 \mathrm{H}$ calves $(304.7 \pm 27.42$ vs. $227.1 \pm 13.43 \mathrm{ng} / \mathrm{mL} ; P=0.01)$ and higher concentrations at $18 \mathrm{~h}$ of life compared with $0 \mathrm{H}$ and $12 \mathrm{H}$ calves $(352.1 \pm 29.17$ vs. $276.8 \pm 23.01$ and $224.9 \pm 13.45 \mathrm{ng} / \mathrm{mL} ; P<0.014)$. These results indicate that delaying colostrum feeding exerts no clear effect on serum IGF-1 concentrations. Although IGF-1 
is present in high concentrations in bovine colostrum (150-310 ng/mL; Malven et al., 1987; Campbell and Baumrucker, 1989; Blum and Hammon, 2000), only a negligible amount of colostral IGF-1 is hypothesized to be absorbed by intestinal enterocytes (Baumrucker and Blum, 1994a; Vacher et al., 1995; Hammon and Blum, 1997). Instead, circulatory IGF-1 appears be derived from endogenous production (Cordano et al., 1998) stimulated by nutrient intake (Hadorn et al., 1997). Therefore, it is not unexpected that calves receiving identical nutrient provision at differing times after birth would not differ in their serum IGF-1 concentrations. Previous work determined that serum IGF-1 concentrations are lower in calves fed $1.5 \mathrm{~L}$ of colostrum at $24 \mathrm{~h}$ of life compared with those fed within the first $2 \mathrm{~h}$ of life (Hammon et al., 2000). However, similar to the present study, no differences were observed between calves fed within $2 \mathrm{~h}$ or calves fed at $6 \mathrm{~h}$ or $12 \mathrm{~h}$. Therefore, colostrum deprivation up to $12 \mathrm{~h}$ after birth may not be sufficient in eliciting responses in circulating IGF-1 concentrations.

Regardless of treatment, there was an effect of time $(P<0.0001)$ for serum IGF-1 concentrations, with the highest concentration $(P<0.036 ; 312.8 \pm 14.85 \mathrm{ng} /$ $\mathrm{mL}$ ) occurring at $48 \mathrm{~h}$ of life compared with all other time points and increasing by $29 \%$ compared with the baseline $(P<0.0001 ; 241.9 \pm 14.06 \mathrm{ng} / \mathrm{mL})$. Baseline serum IGF-1 concentrations collected at $0 \mathrm{~h}$ of life were lower $(P<0.048)$ than concentrations at $6(268.4 \pm$ $13.22 \mathrm{ng} / \mathrm{mL}), 18(284.6 \pm 16.28 \mathrm{ng} / \mathrm{mL}), 24(282.4$ $\pm 12.54 \mathrm{ng} / \mathrm{mL}), 30(275.1 \pm 9.36 \mathrm{ng} / \mathrm{mL})$, and $42 \mathrm{~h}$ $(274.2 \pm 11.82 \mathrm{ng} / \mathrm{mL})$ of life. Interestingly, the maximum concentration at $48 \mathrm{~h}$ of life in the present study is 2 to 7 times greater than previous reports (Hadorn et al., 1997; Hammon et al., 2000; Pyo et al., 2020). However, at $12 \mathrm{~h}$ after their respective colostrum meal, calves were fed MR at 6-h intervals, whereas in previous work calves were fed subsequent meals at $12-\mathrm{h}$ (Hammon et al., 2000; Pyo et al., 2020) and 8- to 15-h (Hadorn et al., 1997) intervals. It may be possible that frequent MR nutrient provision during the first days of life allowed for the continuous endogenous production of IGF-1, thereby allowing calves to reach markedly high concentrations by $48 \mathrm{~h}$ of life. It is also important to note that there are additional hormones that regulate the expression and secretion of IGF-1, including glucagon-like peptide (GLP)-2 (Dubé et al., 2006; Connor et al., 2016), GLP-1 (Cornu et al., 2009), and insulin (Böni-Schnetzler et al., 1991), which are responsive to nutrient provision and feeding time in young dairy calves (Inabu et al., 2018, 2019; Pyo et al., 2020). To explore this further, correlations were performed between IGF-1 and insulin, GLP-1, and GLP-2 concentrations in the calves in the present study (Inabu et al., 2018). However, no correlations were observed between IGF-1 and the aforementioned hormones associated

Table 1. Growth, serum IGF-1 parameters, and small intestinal length and weight of calves fed colostrum $(7.5 \%$ of birth BW; $62 \mathrm{~g}$ of $\mathrm{IgG} / \mathrm{L})$ at $45 \mathrm{~min}(0 \mathrm{H}, \mathrm{n}=9), 6 \mathrm{~h}(6 \mathrm{H}, \mathrm{n}=9)$, or $12 \mathrm{~h}(12 \mathrm{H}, \mathrm{n}=9)$ of life ${ }^{1}$

\begin{tabular}{|c|c|c|c|c|c|}
\hline \multirow[b]{2}{*}{ Parameter $^{2}$} & \multicolumn{3}{|c|}{ Treatment } & \multirow[b]{2}{*}{ SEM } & \multirow[b]{2}{*}{$P$-value } \\
\hline & $0 \mathrm{H}$ & $6 \mathrm{H}$ & $12 \mathrm{H}$ & & \\
\hline Birth BW (kg) & 43.5 & 42.0 & 42.2 & 0.81 & 0.80 \\
\hline Day 2 BW (kg) & 43.8 & 42.7 & 42.8 & 0.80 & 0.88 \\
\hline $\operatorname{ADG}(g / d)$ & 16.7 & 28.1 & 33.3 & 11.22 & 0.83 \\
\hline \multicolumn{6}{|l|}{ IGF-1 } \\
\hline Baseline (ng/mL) & 228.7 & 256.1 & 240.8 & 14.06 & 0.74 \\
\hline Maximum (ng/mL) & 342.6 & 381.3 & 352.0 & 12.98 & 0.46 \\
\hline AUC-TOT & $12,384.0$ & $14,054.2$ & $12,673.7$ & 406.57 & 0.21 \\
\hline $\mathrm{AUC}_{12}$ & $2,922.1^{\mathrm{a}}$ & $3,506.8^{\mathrm{b}}$ & $2,989.6^{\mathrm{a} \dagger}$ & 118.55 & 0.08 \\
\hline $\mathrm{AUC}_{24}$ & $6,200.8^{\mathrm{a} \dagger}$ & $7,239.1^{\mathrm{b} \dagger}$ & $6,406.1^{\mathrm{ab} \dagger}$ & 237.50 & 0.17 \\
\hline $\mathrm{AUC}_{36}$ & $9,157.9$ & $10,543.8$ & $9,561.6$ & 319.13 & 0.19 \\
\hline \multicolumn{6}{|c|}{ Intestinal length ${ }^{3}(\mathrm{~cm} / \mathrm{kg}$ of $\mathrm{BW})$} \\
\hline Duodenum & 0.36 & 0.41 & 0.38 & 0.017 & 0.83 \\
\hline Jejunum & 34.91 & 32.85 & 35.74 & 1.473 & 0.73 \\
\hline Ileum & 10.19 & 8.99 & 9.54 & 0.484 & 0.62 \\
\hline \multicolumn{6}{|c|}{ Intestinal weight ${ }^{3}(\mathrm{~g} / \mathrm{kg}$ of $\mathrm{BW})$} \\
\hline Duodenum & 0.49 & 0.23 & 0.25 & 0.105 & 0.55 \\
\hline Jejunum & 17.15 & 15.95 & 17.90 & 0.701 & 0.54 \\
\hline Ileum & 5.76 & 5.46 & 6.23 & 0.227 & 0.41 \\
\hline
\end{tabular}


with metabolism and gut development, emphasizing the need for future research pertaining to the specific factors that control circulating IGF-1 concentrations after colostrum feeding in young calves.

Colostrum contains a multitude of nutrients and growth factors responsible for proper intestinal development (Baumrucker et al., 1994b; Bühler et al., 1998; Yang et al., 2015) and thereby maximizing nutrient absorption (Han, 1993). Overall, there was no effect of colostrum feeding time on intestinal length $(P>$ 0.62 ; Table 1$)$ and weight $(P>0.41$; Table 1$)$ or on villus height, crypt depth, villus:crypt ratio, and surface area index $(P>0.12$; Figure 1). However, there was a treatment $\times$ segment interaction for villus height, in which $0 \mathrm{H}$ calves had 1.4 times greater villus height in the distal jejunum than both $6 \mathrm{H}(P=0.004)$ and $12 \mathrm{H}$ $(P=0.012)$ calves, and $0 \mathrm{H}$ calves tended $(P=0.073)$ to have 1.2 times greater ileal villus height than $12 \mathrm{H}$ calves (Figure 1a). Furthermore, $0 \mathrm{H}$ calves had deeper ileal crypts than $6 \mathrm{H}(P=0.06)$ and $12 \mathrm{H}(P=0.02)$ calves (Figure 1b). Although the majority of differences in villus:crypt ratio and surface area index reported were tendencies, $0 \mathrm{H}$ calves had a greater $(P=0.02)$ surface area index in the distal jejunum compared with $12 \mathrm{H}$ calves (Figure 1c, d). The jejunum and ileum are the major sites of lipid and peptide absorption (Noble, 1978; Chen et al., 1999). Within these segments, villi increase absorptive surface area by several fold (Mandara and Trier, 1994), allowing for efficient nutrient absorption, and crypts contain actively dividing cells that replace sloughed villus cells (Korinek et al., 1998; Crosnier et al., 2006; Rowland and Brubaker, 2008). Therefore, it is clear that increasing villus height and crypt depth by early colostrum feeding has important implications in gut development and function. However, $\mathrm{OH}$ calves received 1 and 2 additional MR meals at $2.5 \%$ of BW/meal compared with $6 \mathrm{H}$ and $12 \mathrm{H}$ calves, respectively. This resulted in $\mathrm{OH}$ calves having greater nutrient intake than $6 \mathrm{H}$ and $12 \mathrm{H}$ calves over the 51-h study duration. Unfortunately, the extent to which differences in nutrient intake between treatments may have influenced the observed changes in intestinal development is unknown.

A secondary objective of the present study was to qualitatively characterize the ultrastructure of calf enterocytes at $51 \mathrm{~h}$ of life (Figure 2). Brightfield microscopy and ScEM imaging showed that jejunal villi were digitiform and thin, often varying in size (Figure 2a, b). Pinocytosis of intestinal contents was also observed (Figure 2c), similar to the presence of invaginations at the base of microvilli in colostrum-suckled calves (Bessi et al., 2002). An apical canalicular system (ACS) was observed (Figure 2f), which has been shown to fill with material absorbed via nonselective pinocytosis $3 \mathrm{~h}$ after
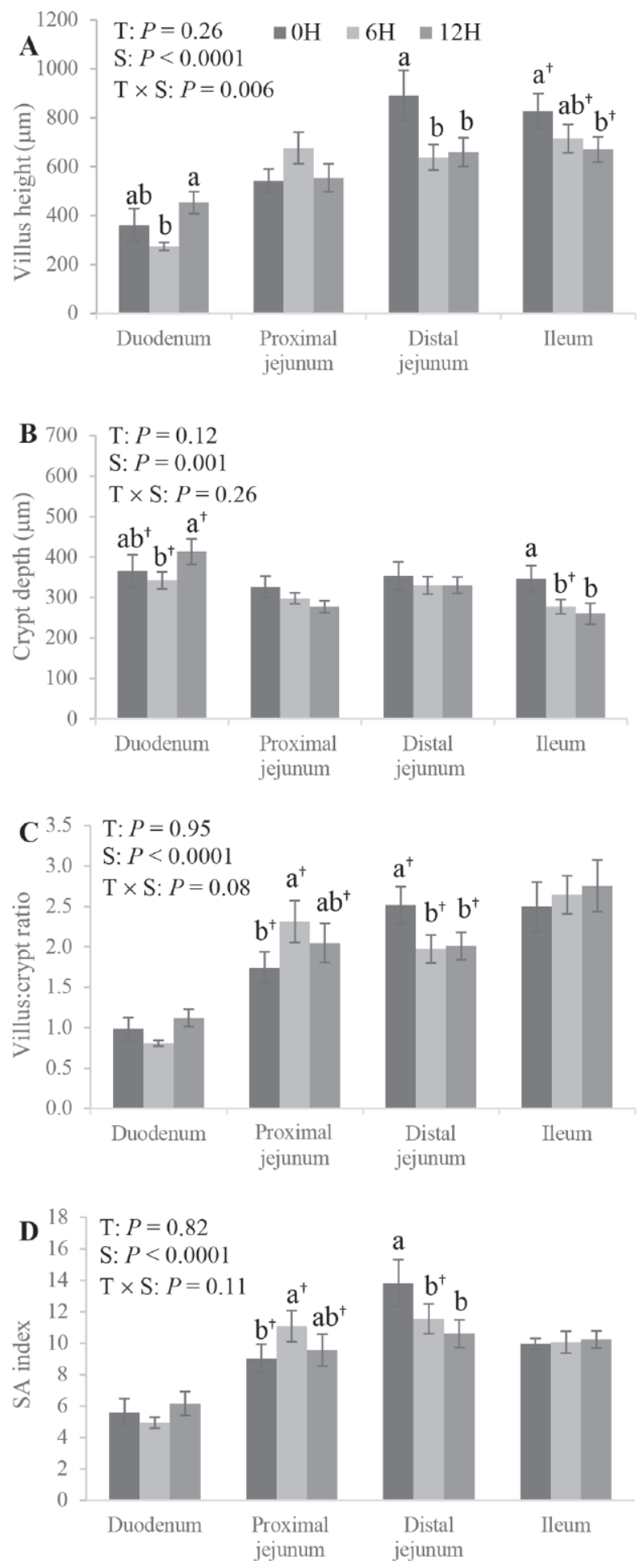

Figure 1. The effect of feeding colostrum (7.5\% of birth BW; $62 \mathrm{~g}$ of $\mathrm{IgG} / \mathrm{L})$ at $45 \mathrm{~min}(0 \mathrm{H}, \mathrm{n}=9), 6 \mathrm{~h}(6 \mathrm{H}, \mathrm{n}=9)$, or $12 \mathrm{~h}(12 \mathrm{H}, \mathrm{n}=9)$ after birth on (A) villus height $(\mu \mathrm{m}),(\mathrm{B})$ crypt depth $(\mu \mathrm{m}),(\mathrm{C})$ villus: crypt ratio, and (D) mucosal surface area (SA) index in neonatal dairy calves at $51 \mathrm{~h}$ of life. Bars represent LSM \pm SEM. Different letters (a, b) represent a significant difference $(P<0.05)$ between treatment $(\mathrm{T})$ within intestinal segment $(\mathrm{S} ; \mathrm{T} \times \mathrm{S})$. Different letters $(\mathrm{a}, \mathrm{b})$ with a dagger $(\dagger)$ represent a tendency $(0.05<P<0.10)$ between $\mathrm{T}$ within $\mathrm{S}(\mathrm{T} \times \mathrm{S})$. 

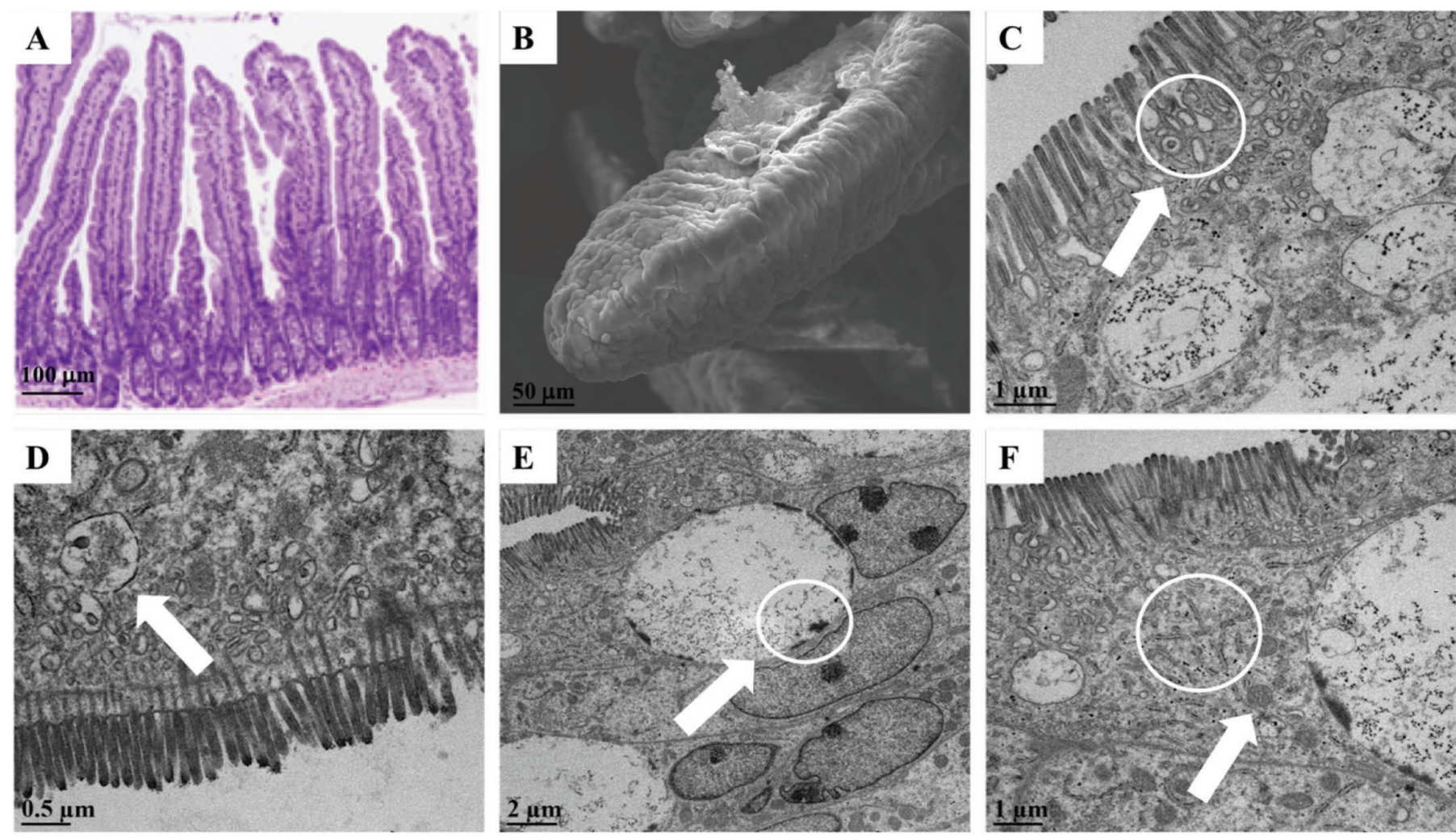

Figure 2. Small intestinal histology, morphology, and ultrastructure of neonatal male Holstein calves at $51 \mathrm{~h}$ of life. (A) Brightfield microscopic image $(100 \times)$ of the proximal jejunum. (B) Scanning electron microscopy image of an ileum villus. (C) Pinocytosis of intestinal contents in the ileum $(14,000 \times)$. (D) Vesicle formation in the ileum $(14,000 \times)$. (E) Formation of a large vacuole containing electron-dense material in the ileum $(5,600 \times)$. (F) Apical canalicular system and apical mitochondria in the ileum $(18,000 \times)$.

colostrum feeding and fuse with vacuoles and discharge their contents into the preformed vacuoles (Bessi et al., 2002). The presence of an ACS and apical and basal mitochondria (Figure 2f) as well as the observed formation of large vacuoles containing electron-dense material (Figure 2d, e) in the jejunum and ileum demonstrated that the calf intestine at $51 \mathrm{~h}$ of life consists of characteristics similar to fetal enterocytes (Bessi et al., 2002; Moretti et al., 2013). The presence of ACS in the jejunum and ileum has been corroborated by previous research in colostrum-fed calves (Bessi et al., 2002), likely due to these segments having the greatest absorption capacity among all small intestinal segments in calves (Jochims et al., 1994). It is important to note that Bessi et al. (2002) observed that the small intestinal ACS was reduced to small apical tubules and nuclei were in a basal position at $3 \mathrm{~d}$ of age, similar to calf enterocytes at 3 wk of age (Landsverk, 1979), both of which are in contrast to the characteristics of calf enterocytes $3 \mathrm{~h}$ after suckling colostrum (Bessi et al., 2002 ) and at $51 \mathrm{~h}$ of life in the present study. These results indicate that small intestinal enterocytes at $51 \mathrm{~h}$ of life display characteristics resembling those of unique fetal enterocytes and have not yet fully transitioned to mature, adult-type enterocytes.

In conclusion, delaying colostrum feeding up to 12 $\mathrm{h}$ of life did not elicit a response in circulating IGF-1 concentrations throughout the first $2 \mathrm{~d}$ of life. However, reduced jejunal and ileal growth was observed in $6 \mathrm{H}$ and $12 \mathrm{H}$ calves compared with $0 \mathrm{H}$ calves, suggesting that delaying colostrum feeding may have negative effects on intestinal development. Furthermore, TEM and ScEM imaging revealed that vacuoles containing electron-dense material were observed in both the jejunum and ileum and that the small intestine displayed characteristics similar to those of fetal enterocytes at $51 \mathrm{~h}$ of life.

\section{ACKNOWLEDGMENTS}

The authors thank the funding support provided by Alberta Livestock and Meat Agency Ltd. (Edmonton, AB, Canada), Alberta Milk (Edmonton, AB, Canada), the Saskatoon Colostrum Co. Ltd. (Saskatoon, SK, 
Canada), and the Natural Sciences and Engineering Research Council of Canada (Ottawa, ON). The authors have not stated any conflicts of interest.

\section{REFERENCES}

Baumrucker, C. R., and J. W. Blum. 1994a. Effects of dietary recombinant human insulin-like growth factors on concentrations of hormones and growth factors in the blood of newborn calves. J. Endocrinol. 140:15-21. https://doi.org/10.1677/joe.0.1400015.

Baumrucker, C. R., M. H. Green, and J. W. Blum. 1994b. Effects of dietary rhIGF-I in neonatal calves on the appearance of glucose, insulin, D-xylose, globulins and $\gamma$-glutamyl transferase in blood. Domest. Anim. Endocrinol. 11:393-403. https://doi.org/10.1016/ 0739-7240(94)90011-6.

Bessi, R., P. Pauletti, R. D. d'Arce, and R. Machado-Neto. 2002. Colostral antibodies absorption in dairy calves. I. Proximal small intestine study. Rev. Bras. Zootec. 31:2314-2324. https://doi.org/ 10.1590/S1516-35982002000900021.

Blättler, U., H. M. Hammon, C. Morel, C. Philipona, A. Rauprich, V. Rome, I. Le Huerou-Luron, P. Guilloteau, and J. W. Blum. 2001. Feeding colostrum, its composition and feeding duration variably modify proliferation and morphology of the intestine and digestive enzyme activities of neonatal calves. J. Nutr. 131:1256-1263. https://doi.org/10.1093/jn/131.4.1256.

Blum, J. W., and H. M. Hammon. 2000. Colostrum effects on the gastrointestinal tract, and on nutritional, endocrine and metabolic parameters in neonatal calves. Livest. Prod. Sci. 66:151-159. https: //doi.org/10.1016/S0301-6226(00)00222-0.

Böni-Schnetzler, M., C. Schmid, P. J. Meier, and E. R. Froesch. 1991. Insulin regulates insulin-like growth factor I mRNA in rat hepatocytes. Am. J. Physiol. 260:E846-E851. https://doi.org/10.1152/ ajpendo.1991.260.6.E846.

Bozzola, J. J., and L. D. Russell. 1992. Electron Microscopy Principles and Techniques for Biologists. Jones and Bartlett Publishers Inc. Boston, MA.

Bühler, C., H. Hammon, G. L. Rossi, and J. W. Blum. 1998. Small intestinal morphology in eight-day-old calves fed colostrum for different durations or only in milk replacer and treated with long- $\mathrm{R}^{3}$ insulin-like growth factor I and growth hormone. J. Anim. Sci. 76:758-765. https://doi.org/10.2527/1998.763758x.

Campbell, P. G., and C. R. Baumrucker. 1989. Insulin-like growth factor-I and its association with binding proteins in bovine milk. J. Endocrinol. 120:21-29. https://doi.org/10.1677/joe.0.1200021.

Chen, H., E. A. Wong, and K. E. Webb Jr.. 1999. Tissue distribution of a peptide transporter mRNA in sheep, dairy cows, pigs, and chickens. J. Anim. Sci. 77:1277-1283. https://doi.org/10.2527/ 1999.7751277x.

Connor, E. E., C. M. Evock-Clover, E. H. Wall, R. L. Baldwin, M. Santin-Duran, T. H. Elsasser, and D. M. Bravo. 2016. Glucagonlike peptide 2 and its beneficial effects on gut function and health in production animals. Domest. Anim. Endocrinol. 56:S56-S65. https://doi.org/10.1016/j.domaniend.2015.11.008.

Cordano, P., H. Hammon, and J. W. Blum. 1998. Tissue distribution of insulin-like growth factor-1 mRNA in 8-day-old calves. Page 188 in Symposium of Growth in Ruminants. J. W. Blum, T. Elsasser, and P. Guilloteau, ed. University of Bern, Bern, Switzerland.

Cornu, M., J.-Y. Yang, E. Jaccard, C. Poussin, C. Widmann, and B. Thorens. 2009. Glucagon-like peptide-1 protects B-cells against apoptosis by increasing the activity of an IGF-2/IGF-1 receptor autocrine loop. Diabetes 58:1816-1825. https://doi.org/10.2337/ db09-0063.

Crosnier, C., D. Stamataki, and J. Lewis. 2006. Organizing cell renewal in the intestine: Stem cells, signal and combinational control. Nat. Rev. Genet. 7:349-359. https://doi.org/10.1038/nrg1840.

Dubé, P. E., C. L. Forse, J. Bahrami, and P. L. Brubaker. 2006. The essential role of insulin-like growth factor-1 in the intestinal trophic effects of glucagon-like peptide-2 in mice. Gastroenterology 131:589-605. https://doi.org/10.1053/j.gastro.2006.05.055.
Fischer, A. J., Y. Song, Z. He, D. M. Haines, L. L. Guan, and M. A. Steele. 2018. Effect of delaying colostrum feeding on passive transfer and intestinal bacterial colonization in neonatal male Holstein calves. J. Dairy Sci. 101:3099-3109. https://doi.org/10.3168/jds 2017-13397.

Godden, S. M., J. E. Lombard, and A. R. Woolums. 2019. Colostrum management for dairy calves. Vet. Clin. North Am. Food Anim. Pract. 35:535-556. https://doi.org/10.1016/j.cvfa.2019.07.005.

Hadorn, U., H. Hammon, R. M. Bruckmaier, and J. W. Blum. 1997. Delaying colostrum intake by one day has important effects on metabolic traits and on gastrointestinal and metabolic hormones in neonatal calves. J. Nutr. 127:2011-2023. https://doi.org/10 $.1093 / \mathrm{jn} / 127.10 .2011$.

Hammon, H., and J. W. Blum. 1997. The somatotropic axis in neonatal calves can be modulated by nutrition, growth hormone and Long-R ${ }^{3}$-IGF-I. Am. J. Physiol. 273:E130-E138. https://doi.org/ 10.1152/ajpendo.1997.273.1.E130.

Hammon, H. M., I. A. Zanker, and J. W. Blum. 2000. Delayed colostrum feeding affects IGF-I and insulin plasma concentrations in neonatal calves. J. Dairy Sci. 83:85-92. https://doi.org/10.3168/ jds.S0022-0302(00)74859-4.

Han, Z. K. 1993. Nutrition Physiology of Farm Animal. Chinese Agricultural Press, Beijing, China.

Inabu, Y., A. Fischer, Y. Song, L. L. Guan, M. Oba, M. A. Steele, and T. Sugino. 2018. Short communication: The effect of delayed colostrum feeding on plasma concentrations of glucagon-like peptide 1 and 2 in newborn calves. J. Dairy Sci. 101:6627-6631. https://doi .org/10.3168/jds.2018-14412.

Inabu, Y., J. Pyo, S. Pletts, L. L. Guan, M. A. Steele, and T. Sugino. 2019. Effect of extended colostrum feeding on plasma glucagon-like peptide-1 concentration in newborn calves. J. Dairy Sci. 102:46194627. https://doi.org/10.3168/jds.2018-15616.

Jehle, P. M., R. D. Fussgaenger, W. F. Blum, N. K. Angelus, A. Hoeflich, E. Wolf, and R. J. Jungwirth. 1999. Differential autocrine regulation of intestinal epithelial cell proliferation and differentiation by insulin-like growth factor (IGF) system components. Horm. Metab. Res. 31:97-102. https://doi.org/10.1055/s-2007 -978705 .

Jeurissen, S. H. M., F. Lewis, J. D. van der Klis, Z. Mroz, J. M. J. Rebel, and A. A. H. M. ter Huurne. 2002. Parameters and techniques to determine intestinal health of poultry as constituted by immunity, integrity, and functionality. Curr. Issues Intest. Microbiol. 3:1-14.

Jochims, K., F. J. Kaup, W. Drommer, and M. Pickel. 1994. An immunoelectron microscopic investigation of colostral IgG absorption across the intestine of newborn calves. Res. Vet. Sci. 57:75-80. https://doi.org/10.1016/0034-5288(94)90085-X.

Kisielinski, K., S. Willis, A. Prescher, B. Klosterhalfen, and V. Schumpelick. 2002. A simple new method to calculate small intestine absorptive surface in the rat. Clin. Exp. Med. 2:131-135. https://doi.org/10.1007/s102380200018.

Korinek, V., N. Barker, P. Moerer, E. van Donselaar, G. Huls, P. J. Peters, and C. Clevers. 1998. Depletion of epithelial stem-cell compartments in the small intestine of mice lacking Tcf-4. Nat. Genet. 19:379-383. https://doi.org/10.1038/1270.

Landsverk, T. 1979. The gastrointestinal mucosa in young milk-fed calves. Acta Vet. Scand. 20:572-582.

Ma, T., E. O'Hara, Y. Song, A. J. Fischer, Z. He, M. A. Steele, and L. L. Guan. 2019. Altered mucosa-associated microbiota in the ileum and colon of neonatal calves in response to delayed first colostrum feeding. J. Dairy Sci. 102:7073-7086. https://doi.org/10.3168/jds 2018-16130.

Malmuthuge, N., Y. Chen, G. Liang, L. A. Goonewardene, and L. L. Guan. 2015. Heat-treated colostrum feeding promotes beneficial bacteria colonization in the small intestine of neonatal calves. J. Dairy Sci. 98:8044-8053. https://doi.org/10.3168/jds.2015-9607.

Malven, P. V., H. H. Head, R. J. Collier, and F. C. Buonomo. 1987. Periparturient changes in secretion and mammary uptake of insulin and in concentrations of insulin and insulin-like growth factors in milk of dairy cows. J. Dairy Sci. 70:2254-2265. https://doi.org/ 10.3168/jds.S0022-0302(87)80285-0. 
Mandara, J. L., and J. S. Trier. 1994. The functional morphology of the mucosa of the small intestine. Pages 1577-1622 in Physiology of the Gastrointestinal Tract. 3rd ed. R. Johnson, ed. Raven Press, New York, NY.

Moretti, D. B., W. M. Nordi, A. L. Lima, P. Pauletti, and R. Machado-Neto. 2013. Enterocyte IgG uptake in the small intestine of goat kids during the period of passive immunity acquisition. Small Rumin. Res. 114:182-187. https://doi.org/10.1016/j.smallrumres .2013.05.012.

Noble, R. C. 1978. Digestion, absorption, and transport of lipids in ruminant animals. Prog. Lipid Res. 17:55-91. https://doi.org/10 .1016/0079-6832(78)90005-8.

Pyo, J., K. Hare, S. Pletts, Y. Inabu, D. Haines, T. Sugino, L. L. Guan, and M. Steele. 2020. Feeding colostrum or a 1:1 colostrum: milk mixture for 3 days postnatal increases small intestinal development and minimally influences plasma glucagon-like peptide-2 and serum insulin-like growth factor-1 concentrations in Holstein bull calves. J. Dairy Sci. 103:4236-4251. https://doi.org/10.3168/ jds.2019-17219.

Rowland, K. J., and P. L. Brubaker. 2008. Life in the crypt: A role for glucagon-like peptide-2? Mol. Cell. Endocrinol. 288:63-70. https:/ /doi.org/10.1016/j.mce.2008.02.014.

Soberon, F., E. Raffrenato, R. W. Everett, and M. E. van Amburgh. 2012. Preweaning milk replacer intake and effects on long-term productivity of dairy calves. J. Dairy Sci. 95:783-793. https://doi .org/10.3168/jds.2011-4391.

Vacher, P.-Y., G. Bestetti, and J. W. Blum. 1995. Insulin-like growth factor-I absorption in the jejunum of neonatal calves. Biol. Neonate 68:354-367. https://doi.org/10.1159/000244256.

Vasseur, E., F. Borderas, R. I. Cue, D. Lefebvre, D. Pellerin, J. Rushen, K. M. Wade, and A. M. de Passille. 2010. A survey of dairy calf management practices in Canada that affect animal welfare. J. Dairy Sci. 93:1307-1316. https://doi.org/10.3168/jds.2009-2429.

von Keyserlingk, M. A. G., and D. M. Weary. 2007. Maternal behavior in cattle. Horm. Behav. 52:106-113. https://doi.org/10.1016/j .yhbeh.2007.03.015.

Weaver, D. M., J. W. Tyler, D. C. VanMetre, D. E. Hostetler, and G. M. Barrington. 2000. Passive transfer of colostral immunoglobulins in calves. J. Vet. Intern. Med. 14:569-577. https://doi.org/10 .1111/j.1939-1676.2000.tb02278.x.

Winder, C. B., C. A. Bauman, T. F. Duffield, H. W. Barkema, G. P. Keefe, J. Dubuc, F. Uehlinger, and D. F. Kelton. 2018. Canadian National Dairy Study: Heifer calf management. J. Dairy Sci. 101:10565-10579. https://doi.org/10.3168/jds.2018-14680.

Yang, M., Y. Zou, Z. H. Wu, S. L. Li, and Z. J. Cao. 2015. Colostrum quality affects immune system establishment and intestinal development of neonatal calves. J. Dairy Sci. 98:7153-7163. https://doi .org/10.3168/jds.2014-9238. 